\title{
Study on Synthesis and Characterization of Anion Exchange Membrane Based on Poly (Vinyl Alcohol) modified by free- radical polymerization
}

\author{
Nguyen Van Thuc*, Nguyen Thi Cam Ha, Nguyen Huu Tho \\ Faculty of Chemistry, VNU-University of Science, 19 Le Thanh Tong, HoanKiem, Hanoi, Vietnam \\ *E-mail: nguyenvanthuc@vnu.edu.vn
}

doi: $10.20964 / 2020.08 .17$

Received: 4 March 2020/ Accepted: 29 April 2020 / Published: 10 July 2020

In this study, poly(vinyl alcohol) (PVA) has been modified by free-radical polymerization (PVAPVA). The formation of products were confirmed by nuclear magnetic resonance spectra $\left({ }^{13} \mathrm{C} \mathrm{NMR}\right)$. The anion exchange membranes based on modified PVA were fabricated in this work. The ionic conductivity, ion-exchange capacity, water uptake of membranes as a function of alkaline concentration and the thermal stability of electrolyte were studied. The obtained membranes have good conductivity $(>1 \mathrm{mS} / \mathrm{cm})$, high anion exchange capacity $(>2 \mathrm{mmol} / \mathrm{g})$, and stable at over $100^{\circ} \mathrm{C}$, meeting the criteria for the anion-exchange membrane for alkaline fuel cell.

Keywords:Poly(vinyl alcohol), membrane, conductivity, fuel cell, polymerization.

\section{$\underline{\text { FULL TEXT }}$}

(C) 2020 The Authors. Published by ESG (www.electrochemsci.org). This article is an open access article distributed under the terms and conditions of the Creative Commons Attribution license (http://creativecommons.org/licenses/by/4.0/). 